\title{
FORUM
}

\section{Ionizing Radiation Quarantine Treatments}

\author{
Guy J. Hallman \\ United States Department of Agriculture, Agricultural Research Service \\ 2301 S. International Blvd., Weslaco, TX 78596, USA.
}

An. Soc. Entomol. Brasil 27(3): 313-323 (1998)

\section{Radiação Ionizante em Tratamentos Quarentenários}

\begin{abstract}
RESUMO - A irradiação é um tratamento de desinfestação em quarentena viável que tem sido estudado nos últimos 40 anos, embora tenha tido pouco uso comercial. Há dois obstáculos principais à aplicação comercial da irradiação: 1) o fato que os insetos não são mortos imediatamente; e 2) a oposição de consumidores à irradiação, a qual tem sido aceita de certa forma, mas permanecendo o impedimento ao uso comercial em grande escala em função de protocolos de aprovação por agências regulamentadoras de países importadores. O Departamento de Agricultura dos Estados Unidos tem tomado os primeiros passos em permitir o movimento de frutas do Havaí ao resto do país que passaram por tratamento de irradiação. As medidas da eficácia dos tratamentos de desinfestação por irradiação devem incluir prevenção da emergência de adultos, quando apenas ovos e larvas estão presentes, ou esterilidade quando as pupas ou adultos estão presentes. Isto pode ser conseguido pelo uso de doses baixas as quais são toleradas por muitas frutas para pragas como moscas tefritídeas, besouros curculionídeos, e alguns Homoptera. Lepidoptera necessitam de doses moderadamente altas. O estágio mais tolerante à radiação é usualmente o mais avançado em seu desenvolvimento. As fêmeas de insetos são mais suscetíveis a radiação que induz esterilidade; alguns ácaros fêmeas (Tetranychidae) são mais tolerantes que os machos. Pesquisas futuras devem se concentrar em confirmar as doses dos tratamentos quarentenários para outras espécies de insetos (isto só tem sido feito para vários tefritídeos); determinar doses para alguns grupos importantes de organismos para os quais pesquisas insuficientes foram conduzidas (Mollusca, Coccoidea, Thysanoptera, Eriophyidae), e identificar e quantificar fatores de radiação modificantes.
\end{abstract}

PALAVRAS-CHAVE: Insecta, Arachnida, radiação gama, irradiação, desinfestação pós-colheita.

ABSTRACT- Irradiation is a viable quarantine disinfestation treatment which has been studied for 40 years although it has received very little commercial use. Two principal obstacles to commercial application, 1) the fact that insects are not killed immediately, and 2) consumer opposition to irradiation, have been allayed to some extent, but the remaining impediment to large-scale commercial use is development of approved protocols by government regulatory 
agencies in importing countries. The United States Department of Agriculture has taken the first step by allowing for the movement of a number of quarantined fruits from Hawaii to the rest of the country following irradiation treatment. The measures of efficacy of irradiation disinfestation treatments should be prevention of adult emergence, when only eggs and larvae are present or sterility when pupae or adults are present. This can be accomplished with relatively low doses that are tolerated by many fruits for such pest groups as tephritid fruit flies, curculionid weevils, and some Homoptera. Lepidoptera will require moderately higher doses. The most radiation-tolerant stage is usually the most advanced one present. Female insects are more susceptible to radiation-induced sterility than males; some spider mite (Tetranychidae) females are more tolerant than males. Future research should concentrate on confirming quarantine treatment doses for more insects (this has only been done for several tephritids), arriving at doses for some important groups of organisms for which scant research has been done (Mollusca, Coccoidea, Thysanoptera, Eriophyidae), and identifying and quantifying radiation-modifying factors.

KEY WORDS: Insecta, Arachnida, gamma radiation, irradiation, postharvest disinfestation.

Quarantines are in place throughout the world to prevent the spread of exotic pests. Nevertheless, materials that may harbor these organisms must often be traded across quarantine boundaries because economic demand for these products exists in areas that are threatened by the pests. When there is an unacceptable risk that a fresh commodity may contain quarantined pests and sufficient evidence exists that a postharvest treatment may kill any quarantined pests present, an importing regulatory agency may allow importation of the commodity if the designated treatment is done according to established protocol. Traditional quarantine treatments have involved one to many hours of temperatures in the range of $43-48^{\circ} \mathrm{C}$, from 12 days to several weeks at temperatures between $0-3^{\circ} \mathrm{C}$, or a few hours of fumigation with products such as ethylene dibromide or methyl bromide. However, changes in international commerce have created the need for alternative quarantine treatments. Ethylene dibromide was banned 15 years ago because it was considered carcinogenic. Continued use of methyl bromide may be lost in the near future because it is regarded to be a stratospheric ozone depleting substance. Cold treatments are lengthy, phytotoxic to some tropical fruits, and susceptible to power interruptions. Also, the rapid transportation systems of today prefer shorter treatments. Heat treatments are damaging to many fruits such as stone fruits, pomes, and avocados. Although hot water immersion is used extensively for mangoes, some damage to the commodity is suffered and less damaging alternatives are sought. Irradiation is a quarantine treatment which has been studied for 40 years, but only applied on a very limited scale recently. Irradiation promises rapid, efficacious quarantine treatments for many pests while causing minimal damage to commodity quality.

A brief history of research on irradiation as a quarantine treatment is given by Burditt, Jr. (1994). Although the process was first conceived by Koidsumi (1930), the first commercial demonstration of irradiation as a quarantine treatment was not done until 1986 when a shipment of mangoes from Puerto Rico was irradiated with $0.75 \mathrm{kGy}$ and sold in Florida. This was a pilot program to look for alternatives to ethylene dibromide. However, hot water immersion was developed to treat mangoes. In April, 1995 limited shipments of Hawaiian-grown fruits began to be shipped 
to the Chicago, Illinois area for irradiation and distribution to vendors (Wong 1998). This practice continues today as the only commercial use of irradiation as a quarantine treatment.

\section{Application of Irradiation}

There are four sources of ionizing radiation for use on food: gamma irradiation using the isotope of 1) cobalt 60 or 2) cesium 137, 3) electron beam (beta particles), or 4) X-ray (bremsstrahlung) radiation produced when an electron beam strikes a converter, which can be any of a number of high density materials. Bremsstrahlung radiation is very similar to gamma ray from isotopes; both can penetrate pallet-loads of produce. A major difference is that bremsstrahlung radiation is concentrated in the same direction as the electron beam; gamma rays from isotopes are emitted in all directions uniformly (isotropic). Electron beam radiation only penetrates a few centimeters, and, thus, its use is limited to small products passing the irradiation source on a conveyor line. Irradiation dose is measured in gray (Gy), which is joules per kilogram. (the discontinued unit is the rad, which equals 0.01 Gy.) Absorbed dose is what is reported, and it is the amount of ionizing radiation energy imparted on the material being irradiated.

Two different logistical strategies have been developed for commercial gamma irradiation: 1) A chamber is loaded with the materials to be irradiated and the radioactive source is raised into the chamber for the appropriate amount of time to achieve the required absorbed dose. 2) A conveyor system carries the materials to be irradiated past the exposed source at a speed which will give the required absorbed dose. The unidirectional nature of electron beam and bremsstrahlung radiation require that they be applied in a conveyor system.

\section{Research Irradiators}

Large-scale commercial irradiators are generally not useful for conducting dosagedetermining research because of the difference between the maximum and minimum absorbed doses received (up to a 3:1 dose uniformity ratio). Research to determine the minimum absorbed dose required for an irradiation quarantine treatment is best conducted with small irradiators, such as a Husman Model 521A (Isomedix, Inc., Whippany, NJ, USA) or Gammacell 220 (MDS Nordion, Kanata, Ontario, Canada) which have at worst a 1.25:1 dose uniformity ratio. These irradiators have a circular array of radioactive-source pencils in the middle of which the product to be irradiated sits. Within these irradiators one can use the centerline or other definable, consistent portion of the irradiator chamber to reduce the dose uniformity ratio even further.

\section{Dosimetry}

As with any treatment, dosimetry is a crucial component of research and application. Irradiation dosimetry is not intuitive as it is with other treatments such as temperature. The irradiator must undergo reference standard dosimetry when it is set up and whenever major modifications are made to the source or apparatus; this is usually performed by the manufacturer. Routine dosimetry must be performed periodically when using an irradiator. Changes in the type, quantity, density, geometry, or arrangement of the product to be irradiated may result in changes in absorbed dose. Radiochromic film (ISP Technologies, Inc., Wayne, NJ, USA) read with a spectrophotometer and properly calibrated to internationally recognized and traceable standards is an acceptable dosimetry system for routine quarantine treatment research. The American Society for Testing and Materials (West Conshohocken, MD, USA) maintains an international subcommittee devoted to dosimetry for radiation processing whose published standards enjoy high regard. Brazilian members include Dr. Linda V. E. Caldas, IPEN-CNEN, São Paulo and Prof. K. E. Collins, Univ. Estadual de Campinas. One 
guide is particularly recommended for those doing irradiation quarantine treatment research: E1900 (1997) Guide for dosimetry in radiation research on food and agricultural products.

\section{Efficacy of Irradiation Quarantine Treatments}

The objective of all quarantine treatments except irradiation is rapid mortality. Irradiation doses needed to cause rapid mortality reduce the quality of fresh commodities. For example, sweetpotato weevil, Cylas formicarius elegantulus (Summers), adults irradiated with $1 \mathrm{kGy}$ lived up to 10 days (Dawes et al. 1987). Even if $1 \mathrm{kGy}$ were sufficient for a sweetpotato weevil quarantine treatment based on adult mortality, sweetpotatoes cannot tolerate $0.4 \mathrm{kGy}$ without significant negative discoloration of the cooked roots (McGuire \& Sharp 1995).

The ultimate objective of a quarantine treatment is to prevent the establishment of exotic pests. Therefore, it is not necessary to kill the pests as long as they can be prevented from developing to the adult stage or prevented from reproducing. Irradiation can accomplish this with relatively low doses tolerated by many fresh commodities. For example, although sweetpotato weevils were not killed rapidly by $1 \mathrm{kGy}$, females were sterilized by $0.2 \mathrm{kGy}$ (Dawes et al. 1987). When developing a quarantine treatment, one should concentrate on the most tolerant stage present in the commodity. In general, as an organism develops it increases in tolerance to irradiation (Table 1). Therefore, the most radiationtolerant stage will be the most developed one found in the commodity. Table 2 recommends objectives for irradiation quarantine treatments based on the most advanced stage present at the time of harvest. Some insects, such as Fuller rose beetle, Asynonychus godmani Crotch, may only be of concern in the egg stage (Johnson et al. 1990). Only tephritid fruit fly eggs and larvae are found in fruits; normally pupae and adults are of no concern. However, because commodities are
Table 1. Dose to achieve $100 \%$ adult mortality of cowpea weevil, Callosobruchus maculatus (F.), irradiated at different life stages (after Diop et al. 1997)

\begin{tabular}{lr}
\hline Stage & Dose $(\mathrm{Gy})$ \\
\hline Egg & 20 \\
7 day-old larva & 20 \\
15 day-old larva & 30 \\
21 day-old larva & 60 \\
Pupa & 140 \\
Flightless adult & $1,500^{1}$ \\
Flight-able adult & $>2,000^{1}$ \\
\hline
\end{tabular}

${ }^{1}$ Mortality within 48 hours.

usually irradiated after being packed and some, such as citrus, may sit at ambient temperatures for a few days before being irradiated, it is conceivable that fruit fly pupae, which are more tolerant of irradiation than larvae, may be present in the packing material before the lot is irradiated (Hallman \& Worley 1998). Some Lepidoptera, such as pyralids and tortricids, pupate within the commodity. A very high dose of radiation is needed to prevent adult emergence from pupae late in development. Therefore, the objective in this case should be sterility of the emerging adults. In many groups of quarantined arthropods (Acari, Homoptera, Hemiptera, Thysanoptera, and Coleoptera) all stages including actively reproducing adults may be present. Therefore, the only possibility for an irradiation quarantine treatment (given that acute mortality of adults requires very high doses) in these cases is sterility.

Brower and Tilton (1985) present irradiation doses needed to sterilize adults of both sexes of 27 stored product Coleoptera and four Lepidoptera. In all cases save one they found that females were equally or more susceptible to radiation-induced sterility than males. The exception was the dermestid Anthrenus flavipes LeConte; while males were sterilized with $50 \mathrm{~Gy}$, females required $80 \mathrm{~Gy}$. Adult female sterility with plant-infesting insects is 
Table 2. Recommended objectives of irradiation quarantine treatments based on most advanced insect stage found at time of treatment.

\begin{tabular}{ll}
\hline Most advanced stage & Objective of treatment \\
\hline Egg & Prevent development beyond first instar \\
Early instars (simple metamorphosis) & Prevent late instar or adult development \\
Early instars (complete metamorphosis) & Prevent pupariation or pupation \\
Late instars & Prevent pupation or adult emergence \\
Pupa & Adult sterility \\
Adult & Sterility \\
\hline
\end{tabular}

also achieved with equal or lower doses than male sterility (Table 3). Another exception is Sharp (1995) who, contradicting Dawes et al. (1987), found that sweetpotato weevil adult females required 300 Gy to sterilize while males required only 150 . Tephritid fruit fly females are sterilized with lower doses applied to late pharate adults than males when both are irradiated for sterile insect release (Hooper 1989). The fact that female insect reproduction is the more susceptible to irradiation of the two sexes is fortunate because research need concentrate only on sterilizing the female regardless of whether it has already mated. The reason that male reproduction is usually more tolerant of irradiation than female reproduction in insects may be due to that fact that the egg is more complex, and, therefore, more susceptible to radiation damage, or it may simply be an artifact of disproportionate numbers. For example, 99.99\% sterility means few eggs will survive while relatively many sperm will.

Except for Tetranychus urticae Koch, female tetranychid mites are more tolerant of irradiation sterility than males (Table 3). Perhaps this is related to parthenogenesis; unfortunately, there are as yet no examples on radiation-induced sterility of parthenogenic insects with which to compare.

\section{Effect of Irradiation on Fresh Commodities}

It goes without saying that any quarantine treatment is worthless if it intolerably damages the commodity to which it is applied. Commodity quality is the other leg of a successful quarantine treatment, and appropriate research on the effects of a treatment to the commodity must be carried out concurrently with efficacy research. In general, any quarantine treatment will cause at the very least a small and negligible amount of damage to fresh fruits and vegetables. Contrary to cursory claims common in the literature, it is rare that a quarantine treatment causes absolutely no detrimental change or, rarer still, enhances the quality of fresh produce. For example, even though immersion of mangoes in hot water reduces certain peel diseases (McGuire 1991), it causes other problems to fruit quality (Smith 1990). Nonetheless, low dose irradiation has been recommended to prolong shelf life and delay ripening of produce and is probably the most broadly applicable quarantine treatment from the standpoint of commodity quality.

An important concern with irradiation quarantine treatments stems from the fact that the treatment will most likely be applied to pallet loads of packed commodities. Therefore, because of distance and attenuation, produce closest to the radiation source will receive up to three times the absorbed dose reaching the farthest produce. Therefore, fresh commodities must tolerate up to three times the absorbed minimum dose required for efficacy. For example, if the minimum absorbed dose to prevent spider mite repro- 
Table 3. Estimated doses required to achieve $100 \%$ sterility in both sexes of many adult insects and mites

\begin{tabular}{lcc}
\hline Order and Arthropod & Dose $(\mathrm{Gy})^{1}$ & Reference \\
\cline { 2 - 3 } & Female Male & \\
\hline
\end{tabular}

COLEOPTERA: Anobiidae

Cigarette beetle, Lasioderma serricorne (F.)

Drugstore beetle, Stegobium paniceum (L.)

175250 Tilton et al. (1966b)

Bostrichidae

Lesser grain borer, Rhyzopertha dominica (F.)

Coccinellidae

Mexican bean beetle, Epilachna varivestis Mulsant

Curculionidae

Boll weevil, Anthonomus grandis Boheman

Plum curculio, Conotrachelus nenuphar (Herbst)

White pine weevil, Pissodes strobi (Peck)

Sweetpotato weevil, Cylas formicarius-

elegantulus (Summers)

Granary weevil, Sitophilus granarius (L.)

Maize weevil, S. zeamais Motschulsky

Dermestidae

Black carpet beetle, Attagenus unicolor (Brahm)

Trogoderma glabrum (Herbst)

Khapra beetle, T. granarium Everts ${ }^{2}$

T. inclusum LeConte

Warehouse beetle, T. variabile Ballion

$300>300$

$50 \quad 50 \quad$ Singh \& Lilies (1972)

$80 \quad 80 \quad$ Henneberry et al. (1964)

$\sim 70>80 \quad$ Earle et al. (1978), Haynes et al. (1978)

$80 \quad 80 \quad$ Jacklin et al. (1970)

$<200>200$ Jaynes \& Godwin (1957)

200300 Dawes et al. (1987)

$300150 \quad$ Sharp (1995)

$<100>100 \quad$ Brown et al. (1972)

$100>100 \quad$ Brown et al. (1972)

Scarabaeidae

European chafer, Rhizotrogus majalis (Razoumowsky)

130175 Tilton et al. (1966a)

$\leq 175250 \quad$ Tilton et al. (1966a)

$60160 \quad$ Nair \& Rahalkar (1963)

$200250 \quad$ Brower \& Tilton (1972)

$100250 \quad$ Brower \& Tilton (1972)

Japanese beetle, Popillia japonica Newman

$25>100$ Chung et al. (1971)

150150 Ladd et al. (1973)

Tenebrionidae

Depressed flour beetle, Palorus subdrepressus (Wollaston)

Yellow mealworm, Tenebrio molitor L.

400400 Brower (1973a)

50150 Brower (1973b)

Dark mealworm, T. obscurus F.

$<100 \quad 100$

Brower (1973b)

HETEROPTERA: Pyrrhocoridae

Cotton stainer, Dysdercus koenigii $\mathrm{F}$.

$2040 \quad$ Srivastava \& Deshpande (1983)

HOMOPTERA: Aleyrodidae

Whitefly, Trialeurodes vaporariorum Westwood

Cicadellidae

Beet leafhopper, Circulifer tenellus (Baker) ${ }^{3}$

Delphacidae

Brown planthopper, Nilaparvata lugens $(\text { Stål })^{3}$

$\leq 50 \quad 60$ Calvitti et al. (1997)

$\sim 50 \sim 180 \quad$ Amereskere \& Georghiou (1971)

Sugarcane delphacid, Perkinsiella saccharicida Kirkaldy ${ }^{3} \quad 35100$ Osborn et al. (1966)

LEPIDOPTERA: Gelechiidae

Angoumois grain moth, Sitotroga cerealella (Olivier)

Pyralidae

Almond moth, Cadra cautella (Walker)

Rice moth, Corcyra cephalonica (Stainton)

1,000>1,000 Cogburn et al. (1966)

$300>500$ Cogburn et al. (1973)

$100>200 \quad$ Huque (1971)

— >350 Chand \& Sengal (1979) 


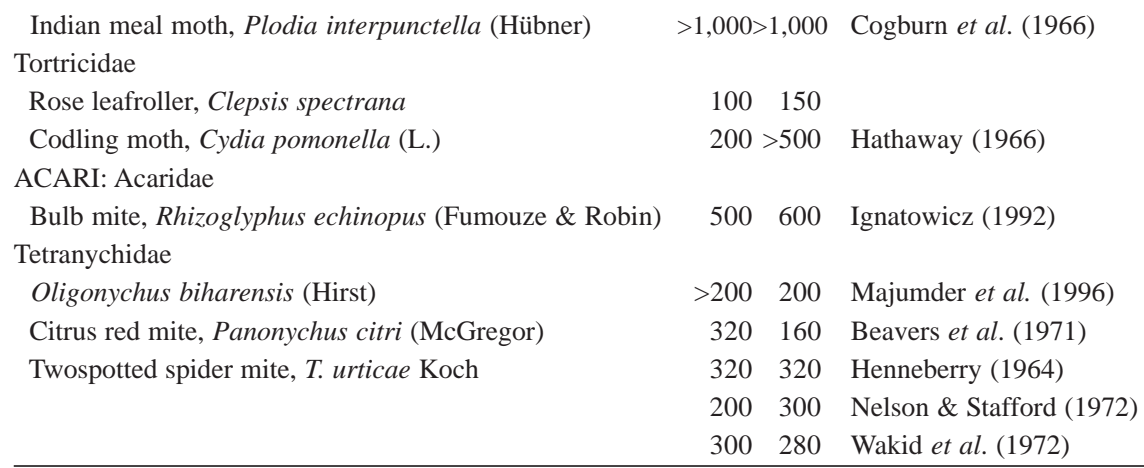

${ }^{1}$ Doses are my interpretation of reported results based on estimation of doses required to provide quarantine security.

${ }^{2}$ Pupae irradiated; dose to sterilize adult would probably be higher.

${ }^{3}$ Fifth instar irradiated; dose to sterilize adult would probably be higher.

duction was set at $0.3 \mathrm{kGy}$, then any produce irradiated for spider mite quarantine would need to be tested for tolerance to up to three times that amount or $0.9 \mathrm{kGy}$.

Morris \& Jessup (1994) review the many effects to the appearance, taste, color, shelf life, texture, chemical content, and pathogens of irradiated produce. Some fruits, such as avocados and atemoyas, are not tolerant of more than low doses, while other, such as papaya, strawberries, pomes, blueberries, cherries, carambolas, and lychees, tolerate $>0.6 \mathrm{kGy}$. The literature of some fruits, such as citrus and mangoes, shows considerable variation in response. As with most quarantine treatments, modifying factors, such as cultivar, maturity, time between harvest and treatment, and post-treatment handling may affect response of the commodity.

\section{Doses to Achieve Quarantine Security}

Doses which might achieve quarantine security against several groups of pests are presented in Table 4. Most of these doses need further research because only tephritids have been done with sufficient numbers of insects to satisfy the degree of confidence demanded of quarantine treatments. Many groups of pests from the important orders
Diptera, Coleoptera, and Homoptera are controlled with relatively low doses which are tolerated by many plant hosts. Other important groups, such as tetranychid mites and Lepidoptera, are controlled by moderate doses (0.2-0.3 kGy) which, when tripled to allow for commercial application, are tolerated by some major commodities, such as apples, cherries, and blueberries.

\section{Conclusions and Future Directions}

Irradiation is a viable quarantine treatment with the potential to disinfest a wide variety of fresh commodities of many quarantined pests. One problem is that irradiation facilities do not widely exist and are expensive to build. However, irradiation facilities have other potential uses, such as parasite and bacterial control in meats and other products, delayed ripening and prolonged shelf life of fresh produce, and sterilization of medical implements. It would be wise to construct facilities at ports or areas which could take advantage of multiple use potential.

Consumer acceptance of irradiated food has not been a problem, although activists opposed to irradiation have been energetic in trying to hinder its use.

Although considerable research on irra- 
Table 4. Absorbed dose ranges which might achieve quarantine security of several pest groups.

\begin{tabular}{lll}
\hline Pest group & Objective & Dose (KGy) \\
\hline Bruchid weevils & Sterilize adult & $0.07-0.1$ \\
Aphids, whiteflies & Sterilize adult & $0.05-0.1$ \\
Tephritid flies & Prevent adult emergence from third instar & $0.05-0.25$ \\
Scarab beetles & Sterilize adult & $0.05-0.15$ \\
Curculionid Weevils & Sterilize adult & $0.1-0.2$ \\
Noctuidae and Tortricidae & Prevent adult emergence from late instar & $0.1-0.3$ \\
Pyralidae and Tortricidae & Sterilize late pupa & $0.2-0.3$ \\
Tetranychid mites & Sterilize adult & $\sim 0.3$ \\
Stored product beetles & Sterilize adult & $0.05-0.4$ \\
Acarid mites & Sterilize adult & $\sim 0.5$ \\
Stored product moths & Sterilize adult & $0.1-1$ \\
Root-knot nematodes & Sterilize adult & $\sim 4$ \\
\hline
\end{tabular}

diation as a quarantine treatment has been performed, scant information exists on radiation-susceptibility of important pest groups, such as molluscs, mealybugs and scales (Homoptera: Coccoidea), thrips (Thysanoptera), and eriophyid mites.

Some factors, especially hypoxia, increase tolerance to irradiation (Hallman \& Worley 1998). Also, response of some fresh commodities, such as mangoes, to irradiation has been quite variable (Morris \& Jessup 1994). Modifying factors must be identified and their effect on the pests and fresh plant products clearly understood so that efficacy in controlling the pests and reduction in damage to commodity quality can be optimized.

The combination of irradiation with other techniques, such as extreme temperatures, should be examined for those commodities and insects which show problems with a single irradiation treatment. Although von Windeguth \& Gould (1990) claimed that a combination irradiation $(50 \mathrm{~Gy})$-cold $\left(1.1^{\circ} \mathrm{C}\right.$ for 5 days) treatment of grapefruits infested with Caribbean fruit fly, Anastrepha suspensa (Loew), resulted in a reduction in dose needed for either treatment done alone, it seems that
50 Gy by itself could have achieved the same level of security as the combination treatment, thus, negating the need for the accompanying cold treatment (von Windeguth \& Ismail 1987).

\section{References Cited}

Ameresekere, R. V. W. E. \& G. P. Georghiou. 1971. Sterilization of the beet leafhopper: induction of sterility and evaluation of biotic effects with a model sterilant (OM-53139) and ${ }^{60} \mathrm{Co}$ irradiation. J. Econ. Entomol. 64: 10741080.

Beavers, J. B., R. B. Hampton, H. H. Toba \& D. S. Moreno. 1971. Some effects of gamma irradiation or the chemosterilant, tepa, on the citrus red mite and its progeny. J. Econ. Entomol. 64: 72-75.

Brower, J. H. 1973a. Depressed flour beetle: sensitivity to gamma irradiation. J. Econ. Entomol. 66: 1318-1320.

Brower, J. H. 1973b. Sensitivity of Tenebrio 
molitor and T. obscurus to gamma irradiation. J. Econ. Entomol. 66: 11751179.

Brower, J. H. \& E. W. Tilton. 1972. Gammaradiation effects on Trogoderma inclusum and T. variabile.J. Econ. Entomol. 65: 250-254.

Brower, J. H. \& E. W. Tilton. 1985. The potential of irradiation as a quarantine treatment for insects infesting stored-food commodities, p. 75-86. In J. H. Moy (ed.) , Radiation disinfestation of food and agricultural products. Honolulu, Univ. of Hawaii, 424p.

Brown, G. A., J. H. Brower \& E. W. Tilton. 1972. Gamma radiation effects on Sitophilus zeamais and S. granarius. J. Econ. Entomol. 65: 203-205.

Burditt, Jr., A. K. 1994. Irradiation, p. 101117. In J. L. Sharp \& G. J. Hallman (eds.), Quarantine treatments for pests of food plants. Boulder, CO, Westview Press, 290p.

Calvitti, M., C. Govoni, M. Buttarazzi \& U. Cirio. 1997. Induced sterility in greenhouse whitefly (Homoptera: Aleyrodidae) treated with gamma radiation. J. Econ. Entomol. 90: 10221027.

Chand, A. T. \& S. S. Sehgal. 1979. Sexual competitiveness of gamma-irradiated adult rice-moth, Corcyra cephalonica Staint. Entomon 4: 111-115.

Chung, S. L., H. Tashiro, P. C. Lippold \& L. M. Massey, Jr. 1971. Gamma irradiation of the European chafer. 2. Determination of sterilization dose levels for adults, with notes on rearing techniques. J. Econ. Entomol. 64: 832837.

Cogburn, R. R., E. W. Tilton \& J. H.
Brower. 1973. Almond moth: gamma radiation effects on the life stages. J. Econ. Entomol. 66: 745-751.

Cogburn, R. R., E. W. Tilton \& W. E. Burkholder. 1966. Gross effects of gamma radiation on the Indian-meal moth and the Angoumois grain moth. J. Econ. Entomol. 59: 682-685.

Dawes, M. A., R. S. Saini, M. A. Mullen, J. H. Brower \& P. A. Loretan. 1987. Sensitivity of sweetpotato weevil (Coleoptera: Curculionidae) to gamma radiation. J. Econ. Entomol. 80: 142-146.

Diop, Y. M., E. Marchioni, D. Ba \& C. Hasselmann. 1997. Radiation disinfestation of cowpea seeds contaminated by Callosobruchus maculatus. J. Food Proces. Preserv. 21: 69-81.

Earle, N. W., L. A. Simmons, S. S. Nilakhe, E. J. Villavaso, G. H. McKibben \& P. Sikorowski. 1978. Pheromone production and sterility in boll weevils: effect of acute and fractionated gamma irradiation. J. Econ. Entomol. 71: 591595.

Hallman, G. J. \& J. W. Worley. 1998. Gamma radiation doses to prevent adult emergence from Mexican and West Indian fruit fly (Diptera: Tephritidae) immatures. J. Econ. Entomol. 91: (in press).

Hathaway, D. O. 1966. Laboratory and field cage studies of the effects of gamma radiation on codling moths. J. Econ. Entomol. 59: 35-37.

Haynes, J. W., J. E. Wright, T. B. Davich, J. Roberson, J. G. Griffin \& E. Darden. 1978. Boll weevil: experimental sterilization of large numbers by fractionated irradiation. J. Econ. Entomol. 71: 943-946. 
Henneberry, T. J. 1964. Effects of gamma radiation on the fertility of the two-spotted spider mite and its progeny. J. Econ. Entomol. 57: 672-674.

Henneberry, T. J., F. F. Smith \& W. L. McGovern. 1964. Some effects of gamma radiation and a chemosterilant on the Mexican bean beetle. J. Econ. Entomol. 57: 813-815.

Hooper, G. H. S. 1989. The effect of ionizing radiation on reproduction, p. 153-164. In A. S. Robinson \& G. Hooper (eds.), Fruit flies their biology, natural enemies and control Vol. 3A. Amsterdam, Elsevier, 372p.

Huque, H. 1971. Effect of gamma radiation on various developmental stages of Corcyra cephalonica Stn. (Gelleridae, Lepidoptera). Internat. J. Appl. Rad. Isotop. 22: 439-441.

Ignatowicz, S. 1992. Irradiation as a quarantine treatment for agricultural products infested by acarid mites (Acarina: Acaridae), p. 157-173. In, Use of irradiation as a quarantine treatment of food and agricultural commodities. Vienna, International Atomic Energy Agency, 220p.

Jacklin, S. W., E. G. Richardson \& C. E. Yonce. 1970. Substerilizing doses of gamma irradiation to produce population suppression in plum curculio. J. Econ. Entomol. 63: 1053-1057.

Jaynes, H. A. \& P. A. Godwin. 1957. Sterilization of the white-pine weevil with gamma radiation. J. Econ. Entomol. 50: 393-395.

Johnson, J. A., E. L. Soderstrom, D. G. Brandl, L. G. Houck \& P. L. Wofford. 1990. Gamma radiation as a quarantine treatment for Fuller rose beetle eggs (Coleoptera: Curculionidae) on citrus fruit. J. Econ. Entomol. 83: 905-909.

Koidsumi, K. 1930. Quantitative studies on the lethal action of $\mathrm{x}$-rays upon certain insects. J. Soc. Tropical Agr. 2: 243-263.

Ladd, Jr., T. L., R. T. Canfield \& A. J. Forgash. 1973. Sterilization of Japanese beetles by gamma radiation. J. Econ. Entomol. 66: 1047-1048.

Majumder, M. Z. R., A. D. Bhuiya \& N. Chowdhury. 1996. Effects of radiation on mortality, fecundity and sterility of Oligonychus biharensis (Hirst) infesting common flower plants in Bangladesh. Bangladesh J. Zool. 24: 25-32.

McGuire, R. G. 1991. Concomitant decay reductions when mangoes are treated with heat to control infestations of Caribbean fruit flies. Plant Disease 75: 946-949.

McGuire, R. G. \& J. L. Sharp. 1995. Market quality of sweetpotatoes after gammairradiation for weevil control. HortScience 30: 1049-1051.

Mochida, O. 1973. Effect of gamma radiation on the development and reproduction of the brown planthopper, Nilaparvata lugens (Stål) (Homoptera: Delphacidae). Appl. Ent. Zool. 8: 113-127.

Morris, S. C. \& A. J. Jessup. 1994. Irradiation, p. 163-190. In R. E. Paull \& J. W. Armstrong (eds.), Insect pests and fresh hortic. products: treatments and responses. Wallingford, England, CAB International, 360p.

Nair, K. K. \& G. W. Rahalkar. 1963. Studies on the effects of gamma radiation on the different developmental stages of the Khapra beetle, Trogoderma granarium Everts, p. 465-477 In, Radiation and radioisotopes applied to insects of agricul. importance IAEA, Vienna. 
Nelson, R. D. \& E. M. Stafford. 1972. Effects of gamma radiation on the biology and population suppression of the twospotted spider mite, Tetranychus urticae Koch. Hilgardia 41: 299-341.

Osborn, A. W., E. Shipp \& P. B. Hutchinson. 1966. Biology and radiation sterilization of sugar cane leafhoppers. Atomic Energy Australia 9(4): 3-11.

Sharp, J. L. 1995. Mortality of sweetpotato weevil (Coleoptera: Apionidae) stages exposed to gamma irradiation. J. Econ. Entomol. 88: 688-692.

Singh, H. \& J. N. Lilies. 1972. Effects of gamma rays on the acute lethality and reproductive potential of lesser grain borer adults. J. Econ. Entomol. 65: 656659.

Smith, E. S. C. 1990. Fruit fly disinfestation in mangoes by hot water dipping, p. 188195. In, Proc. 3rd internat. conf. on plant protec. in the tropics, Genting Highlands, Pahang, Malaysia, Malaysia Plant Protec. Soc.

Srivastava, K. P. \& D. J. Deshpande. 1983. Effect of X-irradiation on fecundity, fertility \& longevity of the red cotton bug Dysdercus koenigii Fabr. Indian J. Experimental Biol. 21: 604-606.

Tilton, E. W., W. E. Burkholder \& R. R. Cogburn. 1966a. Effect of gamma radiation on Trogoderma glabrum and Attagenus piceus. J. Econ. Entomol. 59: 944-948.

Tilton, E. W., W. E. Burkholder \& R. R. Cogburn. 1966b. Effects of gamma radiation on Rhyzopertha dominica, Sitophilus oryzae, Tribolium confusum, and Lasioderma serricorne. J. Econ. Entomol. 59: 1363-1368.

von Windeguth, D. L. \& W. P. Gould. 1990. Gamma irradiation followed by cold storage as a quarantine treatment for Florida grapefruit infested with Caribbean fruit fly. Fla. Entomol. 73: 242-247.

von Windeguth, D. L. \& M. A. Ismail. 1987. Gamma irradiation as a quarantine treatment for Florida grapefruit infested with Caribbean fruit fly, Anastrepha suspensa, (Loew). Proc. Fla. State Hort. Soc. 100: 5-7.

Wakid, A. M., E. A. Elbadry \& M. A. Alaal. 1972. Effects of gamma radiation on the fertility of the spider mite, Tetranychus arabicus Attiah. Ann. Zool. Ecol. Anim. 4: 375-378.

Wong, L. 1998. Recent experience and problems in shipment, irradiation and marketing Hawaiian fruits in the United States. p. In J. H. Moy (ed.), The use of irradiation as a quarantine treatment of food and agricultural commodities. Honolulu, Univ. of Hawaii. (in press). 